\title{
Movement of Southern Elephant Seals (Mirounga leonina L.) from Elephant Is. South Shetlands, Antarctica
}

\author{
Mônica M. C. Muelbert ${ }^{1 *}$, Ricardo B. Robaldo ${ }^{2}$, Pablo E. Martínes ${ }^{2}$, Elton P. Colares ${ }^{2}$, \\ Adalto Bianchini ${ }^{2}$ and Alberto Setzer ${ }^{3}$ \\ ${ }^{1}$ Museu Oceanográfico "Prof. Eliézer de C. Rios" - MOFURG; Fundação Universidade Federal do Rio Grande - \\ FURG; mamiferos@furg.br; C.P. 379; 96200-970; Rio Grande - RS - Brazil. ${ }^{2}$ Departamento de Ciências \\ Fisiológicas; Fundação Universidade Federal do Rio Grande - FURG; C. P. 474; 96201-900; Rio Grande - RS - \\ Brazil. ${ }^{3}$ INPE; C. P. 515; 12201-970; São José dos Campos - SP - Brazil
}

\begin{abstract}
In 1999, at-sea activity of two young southern elephant seal males (Mirounga leonina) from Elephant Is. $\left(61^{\circ} 13^{\prime} S\right.$, $55^{\circ} 23^{\prime} \mathrm{W}$ ), Antarctica, was monitored and tracked for 9 months. The individuals were randomly selected, captured, sedated (Zoletil 50®- $1 \mathrm{mg} / \mathrm{kg}$ ), weighed, measured, bled, paint-marked and fitted with satellite tags (STDR - ST6PPT, Telonics®, USA). Deployment of the STDR took about 45 min since each animal had a lower incisor tooth extracted for age determination. The seals exhibited individual behaviors. Seal "V"-23842 (BM 801kg) moved

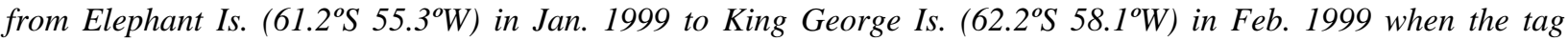
stopped signaling. Seal “T”-23843 (BM $\sim 656 \mathrm{~kg})$ was restricted to the area around Elephant Is. $\left(61.2^{\circ} \mathrm{S} 54.4^{\circ} \mathrm{W}-\right.$ $\left.61.6^{\circ} \mathrm{S} 55.4^{\circ} \mathrm{W}\right)$ from January to May 1999, when it started to move south-eastwards. Although the age of these individuals was not yet determined it was likely to explain the difference in the two patterns of movement reported here. The temporal and spatial association of these movements with areas of high productivity is being investigated to assess whether the observed distribution reflects foraging activity.
\end{abstract}

Key words: Mirounga leonina; southern elephant seals; satellite telemetry; Antarctica; at-sea activity

\section{INTRODUCTION}

Elephant seals (Mirounga spp.) are proficient divers who exhibit long, deep and often continuous dives (Le Boeuf et al. 1986,1988,1989; Boyd and Arnbom, 1991; Hindell, Slip and Burton, 1991; Stewart and DeLong 1991; Campagna et al. 1995). They are reported to be part of complex predator-prey interactions in marine ecosystems (Croxall et al. 1985). As a result, it has been suggested that they play an important role in marine food webs. Thus, information about the pelagic phase of their life cycle is crucial not only for a better understanding of their biology, ecology and physiology but also to help us understand about the influence that both small and large scale environmental changes might have over their populations.

Recent studies have shown that seasonal movements exhibited by elephant seals were not restricted to the areas close to their natal colonies (Stewart and DeLong 1991; Boyd and Arnbom, 1991; Hindell, Slip and Burton, 1991; Campagna et al. 1995; Le Boeuf et al. 1993; Le Boeuf 1994; present study). Southern elephant seals, $M$. leonina, tracked over the post-breeding seasons

\footnotetext{
* Author for correspondence
} 
have been reported to use distant foraging areas which are usually associated with the Antarctic Polar Front, continental shelf margins or ice edge (Boyd and Arnbom 1990; Hindell, Slip and Burton, 1991; Fedak et al. 1994; Jonker and Bester 1998). Their overall movement shows that most of the Southern Ocean is potentially available to these seals as foraging grounds. It has been suggested that since they migrate long distances, dive to great depths and return to natal areas at a somewhat predictable pattern, elephant seals would appear to be suitable platforms for monitoring ecosystem changes in open oceans (van der Hoff and Burton 2001).

Although information on at-sea activities, dispersion and seasonal movements of most Southern elephant seal populations is becoming more and more frequent, there is virtually no record about the activities exhibited by SES from Elephant Is. $\left(61^{\circ} 13^{\prime} \mathrm{S}, 55^{\circ} 23^{\prime} \mathrm{W}\right)$, Antarctica. Until fairly recently, there were no reports of breeding activity occurring on the island and the presence of individuals year-round was questioned. The objective of this study was to describe the pelagic phase of the life cycle of southern elephant seals (Mirounga leonina) from Elephant Is. $\left(61^{\circ} 13^{\prime} \mathrm{S}\right.$, $55^{\circ} 23^{\prime} \mathrm{W}$ ), Antarctica, in order to give us information about part of the behavior of those individuals.

\section{MATERIALS AND METHODS}

Seasonal movements of two young of southern elephant seals (Mirounga leonina) from Long Beach, Elephant Is. (61 $\left.{ }^{\circ} 13^{\prime} \mathrm{S}, \quad 55^{\circ} 23^{\prime} \mathrm{W}\right)$, Antarctica, were monitored. In January 1999, two males were randomly selected from a postbreeding group, physically restrained, captured, sedated, weighed, measured, bled, paint-marked and fitted with satellite tags (STDRs - ST-6PPT, Telonics®, USA). Seal "V" (tag number 23842) weighed approximately $801 \mathrm{~kg}( \pm 1,0 \mathrm{~kg})$ and was $310 \mathrm{~cm}$ long while seal "T" (tag number 23843) weighed approximately $656( \pm 1,0 \mathrm{~kg}) \mathrm{kg}$ and was $303 \mathrm{~cm}$ long. Their at-sea movements were monitored for periods of $39 \mathrm{~d}$ and 252 days, respectively, after their annual molt.

During instrument deployment the individuals were chemically immobilized with Zoletil $50 \circledast(1 \mathrm{mg} / \mathrm{kg})$ which was administered via intramuscular injection as described by Martinez et al. (1998) and Baker et al. (1990). The tag was secured by two cable ties to an epoxy mount 12 $\mathrm{cm}$ long and $8 \mathrm{~cm}$ wide which had a piece of nylon mesh about $20 \mathrm{~cm}$ long and $15 \mathrm{~cm}$ wide embedded in the base of the mount as described for harbour seals (Boness et al. 1994, Muelbert 1998). The complete mount weighed about $1.2 \mathrm{~kg}$ (a maximum of $2 \%$ body mass) and was glued to the animal's fur using a 5-min epoxy. Deployment of the STDR took about 45 min since each animal had a lower incisor tooth extracted for age determination. The individuals were closely monitored until full recovery.

Daily surveys conducted throughout the season ensured that the actual time of departure from the island was known and to verify the information received from the tags. The two individuals were monitored on land until a week after deployment suggesting that there was no side effects to the procedure.

The data was received by the Environment Data logger at the Brazilian field station (EACF) in King George Is $\left(62.2^{\circ} \mathrm{S} 58.1^{\circ} \mathrm{W}\right)$. Due to logistic problems, we were unable to process water temperature and depth information.

\section{RESULTS}

Even though two individuals were fitted with satellite tags, only one tag transmitted for more than a month. Therefore, although we have an account of the movements exhibited by both seals for at least a month.

The initial movement of the two post-molting males differed from that of other southern elephant seals in that they remained fairly close to Elephant Is. (Fig. 1 - insets), at least during the month of January. The area where they were distributed was reported to be around $200 \mathrm{~m}$ deep, which corresponded to depths of continental shelf areas and where benthic and demersal prey species were likely to occur. During the first month, both individuals exhibited not only similar movements (Table 1) but their overall distribution overlapped considerably (Fig. 1 - insets). However, by the end of January this situation changed. Seal "V" (tag 23842) moved from Elephant Is. $\left(61.2^{\circ} \mathrm{S} 55.3^{\circ} \mathrm{W}\right)$ to King George Is. $\left(62.2^{\circ} \mathrm{S} 58.1^{\circ} \mathrm{W}\right)$ such that by Feb. 22,1999 it was $290 \mathrm{~km}$ away from its starting point after 39 days (Table 1). The tag from seal "V" failed shortly after the seal started to move west of Elephant Is. towards King George Is. This individual was not resighted the following season. 
The movements from seal "T" (tag 23843) were restricted to the area around Elephant Is. $\left(61.2^{\circ} \mathrm{S}\right.$ $54.4^{\circ} \mathrm{W}$ to $61.6^{\circ} \mathrm{S} 55.4^{\circ} \mathrm{W}$ ). From late January to approximately May 1999, it remained near the island in an area that was on average $200 \mathrm{~m}$ deep (Fig. 1- inset). In June 1999, seal "T" (tag 23843) started to move south-eastwards about $110 \mathrm{~km}$ away from its starting point to an area reported to be 500 to $2000 \mathrm{~m}$ deep where it was likely to find mesopelagic and bathypelagic prey species. Male "T" remained in this area until late September when the tag stopped transmitting, representing a total movement of roughly $794 \mathrm{~km}$ in 252 days. The seal was sighted on November 17, 2000 during a daily beach survey the following breeding season at Long Beach, Elephant Is. $\left(61^{\circ} 13^{\prime} \mathrm{S}\right.$, $55^{\circ} 23^{\prime} \mathrm{W}$ ) when the tag was recovered.

The lack of temperature, depth and detailed dive information prevented a more detailed description of the diving activities.

However, oceanographic and bathymetric data from the area gave us some idea on general environmental conditions.

Table 1 - Information on actual movement, direction and record duration obtained from satellite transmitters deployed in two post-moulting southern elephant seal males.

\begin{tabular}{c|c|c|c|c|c|c}
\hline Movement & \multicolumn{3}{|c|}{ Total } & \multicolumn{3}{c}{ Partial (1 $\mathbf{1}^{\text {st }}$ month) } \\
\hline Individuals & $\begin{array}{c}\text { distance } \\
(\mathbf{k m})\end{array}$ & direction & $\begin{array}{c}\text { duration } \\
(\mathbf{d a y s})\end{array}$ & $\begin{array}{c}\text { distance } \\
(\mathbf{k m})\end{array}$ & direction & $\begin{array}{c}\text { duration } \\
(\mathbf{d a y s})\end{array}$ \\
\hline Seal "V" (23842) & 292.6 & $\mathrm{SW}$ & 39 & 120.3 & E. Is. & 13 \\
Seal "T" (23843) & 794.2 & $\mathrm{SE}$ & 252 & 124.9 & E. Is. & 8 \\
\hline
\end{tabular}

\section{DISCUSSION}

The significance of this study was limited by the small sample size and the lack of water temperature, depth and dive characteristics. Nevertheless, there were no previously published records of seasonal movements of southern elephant seals from Elephant. Is. Furthermore, regardless the lack of information linking hydrographic and oceanographic data and potential prey distribution, the results presented herein provide information on potential foraging areas for the South Georgia stock, specially the area situated about $110 \mathrm{~km}$ south-eastwards of Elephant Island (Fig. 1).

Although the results presented here could be considered preliminary which prevented conclusive statements about the overall movement of southern elephant seals from Elephant Is., some interesting findings emerged. There was a correspondence between the areas chosen by postbreeding southern elephant seal females (Fedak et al. 1994) and post-molting males (this study). McConnell et al. (1992) suggested that southern elephant seals would travel to areas with relocatable hydrographic or topographic features such as shelf breaks so that prey could be consistently located. The areas south of Elephant Is. used by both males in the present study are similar to the areas used by post-breeding female southern elephant seals tagged in South Georgia in 1990 (Fedak et al. 1994). The females left South Georgia and traveled south to Elephant Is. to forage. The overall distribution of seal " $T$ " (23843 - Fig. 1) was very similar to that exhibited by seal "3" (Fig. 20.4 from Fedak et al. 1994). On the other hand, the movement of seal "V" (Fig. 123842) was similar to that of seal " 1 " from Fedak et al. (op. cit.). which traveled from South Georgia to the continental shelf margin $110 \mathrm{~km}$ west of Adelaide Is. in 70 days. It is possible that individual "V" was traveling to the same general area along the continental shelf break as did seal 1 (Fedak et al. 1994). However, since the tag stopped transmitting a week after seal "V" reached King George Is., we were unable to make any conclusive statements.

Current evidence suggests that southern elephant seals feed primarily on squid (Laws 1977; Clark and McAllen 1982) which concentrate at depths greater than $300 \mathrm{~m}$ and on benthic or demersal species (Rodhouse et al. 1992). 

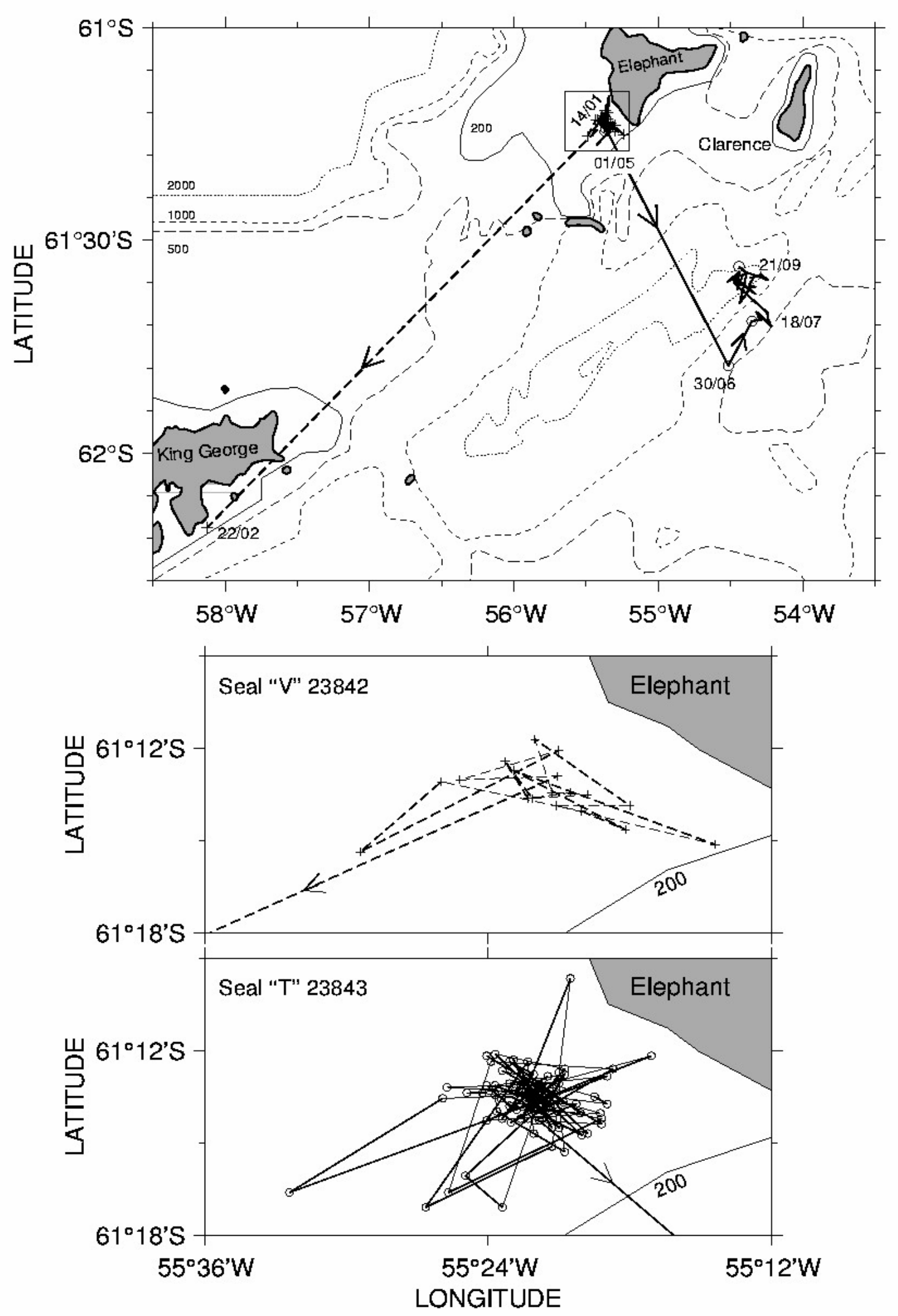

Figure 1 - Individual tracks exhibited by males "V" 23842 (dotted line) and "T" 23843 (solid line) around the South Shetlands. Notice that overlap exhibited during the first month of monitoring (insets). 
However, in the Southern Ocean squid could be also found at shallower depths at night as a result of diel migrations (Rodhouse 1988). The areas where seals "V"(23842) and "T"(23843) traveled to during the initial stages of the present monitoring study were on average $200 \mathrm{~m}$ deep (Fig. 1) where demersal squid and benthic octopods may occur. Although we were unable to determine dive profiles and time of diving activities it is likely that these males were foraging on such prey Elephant Is., although its presence in the area might have been missed on daily beach surveys for tag resighting. It is likely that the distinct patterns of movement exhibited by seals "V" and " $T$ " reported here reflected different developmental stages of these individuals, even though both males could be assigned to the same male-size category established by Lewis (1996), as subadult males III. Age determination might contribute to explain the observed patterns. Genetic studies have shown the high degree of movement exhibited by elephant seals (Fabiani et al. 2003) which may also explain some of these differences.

Water temperature, depth information and dive characteristics would have been helpful in determining diving behavior and environmental clues associated with diving activity and foraging. The idea of elephant seals as suitable platforms for monitoring ecosystem changes in open oceans, as proposed by van der Hoff and Burton (2001), could be promising given the fact that they travel to areas covered by sea-ice where most ships are unable to go; they are capable of carrying sensor packages successfully that could be retrieved in an yearly basis; and, given their diving capabilities they could monitor oceanographic variables and profiles as they forage.. However, this would only be possible if technological advances are to be made in order to minimize instrument failure and loss of data given the high costs associated with Antarctic research.

The movement of southern elephant seals reported here are consistent with movements exhibited by elephant seals elsewhere. However, they suggested that not all southern elephant seals have to travel long distances searching for foraging grounds. It is likely that southern elephant seals from Elephant Is. were using the same foraging grounds as southern elephant seals from South Georgia and that at least for part of the year, feed on benthic or demersal prey. This behavior might reflect a compromise between the energy expenditure associated with food acquisition and local prey energy content. The use of distant foraging areas for elephant seals from Elephant Is. was not needed given the proximity of probable foraging areas for both demersal and benthic prey as well as meso and bathypelagic species. The present work represents a small step towards the development of a broader and more detailed monitoring program of the at-sea behavior of southern elephant seals from Elephant Is. It should also aid to establish a relationship between their movements and interactions with the oceanic environment.

\section{ACKNOWLEDGMENTS}

We thank Commander André Más and the crew from Research Vessel N.Ap.Oc. "Ary Rongel" from the Brazilian Navy, the personnel from the Brazilian Antarctic Station "Comandante Ferraz" (EACF) for field assistance and logistic support. We would also like to thank the "Southern Elephant Seal Project" team for field support. We are grateful to José H. Muelbert and Fernanda M. Costa for their revisions, comments, technical and advisory support. This research was made possible to grants from the Brazilian National Research Council (Conselho Nacional de Desenvolvimento Científico e Tecnológico - $\mathrm{CNPq}$ ) to $\mathrm{AB}$ and MMCM, and a grant from the Rio Grande do Sul State Research Foundation (Fundação de Amparo à Pesquisa do Estado do Rio Grande do Sul FAPERGS) to MMCM.

\section{RESUMO}

O presente estudo descreve os movimentos de dois exemplares de elefante-marinho do sul (Mirounga leonina) durante a fase pelágica de seu ciclo de vida. Os exemplares foram capturados no verão austral de 1999 na Ilha Elefante $\left(61^{\circ} 13^{\prime} \mathrm{S}\right.$, $\left.55^{\circ} 23^{\prime} \mathrm{W}\right)$, Antártica, e monitorados por aproximadamente 9 meses. Cada exemplar foi instrumentado com um medidor de tempo e profundidade de mergulho via satélite (Sattelite Time Depth Recorder, STDR mod. ST-6PPT, Telonics $^{\circledR}$, EUA) com uma antena VHF acoplada ao instrumento, montado num molde de tela e resina, fixado com cintas plásticas, e colados na pelagem dorsal do animal com resina plástica. Para a instrumentação o animal era capturado com rede 
de contenção e imobilizado quimicamente com anestésico dissociativo (Zoletil $50^{\circledR}-1 \mathrm{mg} / \mathrm{kg}$ ). Um dos indivíduos (23842), deslocou-se da Ilha Elefante $\left(61.2^{\circ} \mathrm{S} 55.3^{\circ} \mathrm{W}\right)$ até a Ilha Rei George $\left(62.2^{\circ} \mathrm{S} 58.1^{\circ} \mathrm{W}\right)$ em fevereiro quando perdemos contato com o instrumento. Já o indivíduo 23843 permaneceu nas águas ao redor da Ilha Elefante $\left(61.2^{\circ} \mathrm{S} 54.4^{\circ} \mathrm{W}\right.$ a $\left.61.6^{\circ} \mathrm{S} 55.4^{\circ} \mathrm{W}\right)$ por grande parte do ano (janeiro à setembro), quando começou a deslocar-se para SW. Este indivíduo foi reavistado na temporada de 1999/2000 quando o instrumento foi recuperado. Os deslocamentos registrados podem estar relacionados com o estágio de desenvolvimento de cada indivíduo. O presente estudo demonstra a viabilidade de estudos de monitoramento de elefantes-marinhos das Ilhas Shetlands do Sul, Antártica, através de telemetria por satélite e a necessidade da continuidade destes estudos num maior número de indivíduos para uma descrição mais detalhada dos padrões de migração, distribuição e forrageio apresentados.

\section{REFERENCES}

Arnbom, T. A.; Lunn, N. J.; Boyd, I. L. and Barton, T. (1992), Ageing live Antarctic fur seals and southern elephant seals. Marine Mammal Science, 8, 37-43.

Baker, J. R.; Fedak, M. A.; Anderson, S. S.; Arnbom, T. and Baker, R. (1990), Use of tiletamine-zolazepan mixture to immobilise grey seals and southern elephant seals. Veterinary Records, 126, 75-77.

Boness, D. J.; Bowen, W. D. and Oftedal, O. T. (1994), Evidence of a maternal foraging cycle resembling that of otariid seals in a small phocid, the harbor seal. Behavioural Ecology and Sociobiology, 34, 95-104.

Boyd, I. L. and Arnbom, T. (1991), Diving behavior in relation to water temperature in the southern elephant seal - foraging implications. Polar Biology, 11 : (4), 259-266.

Campagna, C.; LeBoeuf, B. J.; Blackwell, S. B.; Crocker, D. E. and Quintana, F. (1995), Diving behavior and foraging location of female southern elephant seals from Patagonia. Journal of Zoology, 236 : (1), 55-71.

Clark, M. R. and McAllen, N. (1982), Cephalopods in the diet of elephant seals at Singe Island, South Orkney Islands. British Antarctic Survey Bulletin, 57, 27-31.

Croxall, J. P.; Prince, P. A. and Ricketts, C. (1985), Relationships between prey life-cycles and the extent, nature and timing of seal and seabird predation in the Scotia Sea. In: Siegfried, W. R.; Condy, P. R. and Laws, R. M. (eds.). Antarctic nutrient cycles and food webs. Berlin : Springer. pp. 516-533.

Fabiani, A.; Hoelzel, A. R.; Galimberti, F. and Muelbert, M. M. C. (2003), Long-range paternal gene flow in the Southern Elephant Seal. Science, 299, 676.

Fedak, M. A.; Arnbom, T.; McConnell, B. J.; Chambers, C.; Boyd, I. L.; Harwood, J. and McCann, T. S. (1994), Expenditure, Investment, and Aquisition of energy in Southern Elephant seals. In: Le Boeuf, B. J. and Laws, R. M. (eds.). Elephant seals: Population ecology, behaviour, and Physiology. Berkley : University of California Press. pp. 354-373.

Hindell, M. A.; Burton, H. R. and Slip, D. J. (1991), Foraging areas of southern elephant seals, Mirounga leonina, as inferred from water temperature data. Australian Journal of Marine and Freshwater Research, 42, 115-128.

Hindell, M. A.; Slip, D. J.; Burton, H. R. and Bryden, M. M. (1992), Physiological implications of continuous, prolonged, and deep dives of the southern elephant seal (Mirounga leonina). Canadian Journal of Zoology, 70 : (2), 370-379.

Jonker, F. C. and Bester, M. N. (1998), Seasonal movements and foraging areas of adult southern female elephant seals, Mirounga leonina, from Marion Island. Antarctic Sciences, 10 : (1), 21-30.

Laws, R. M. (1977), The significance of vertebrates in the Antarctic marine ecosystem. In: Lan, G. A. (ed.). Adaptations within Antarctic Ecosystems. Proceedings of the $3^{\text {rd }}$ SCAR Symposium in Antarctic Biology. Washington, DC. : Smithsonian Institute. pp. 411-428.

Le Boeuf, B.J., Costa, D.P., Huntley, A.C., Kooyman, G.L. and Davies, R.W. (1986), Pattern and depth of dives in northern elephant seals, Mirounga angustirostris. Journal of Zoology, London 208-1-7.

Le Boeuf, B. J.; Costa, D. P.; Huntley, A. C. and Feldkamp, S. D. (1988), Continuos, deep diving in female northern elephant seals, Mirounga angustirostris. Canadian Journal of Zoology, 66, 446-458.

Le Boeuf, B. J.; Naito, Y.; Huntley, A. C. and Asaga, T. (1989), Prolonged, continuos, deep diving by northern elephant seals. Canadian Journal of Zoology, 67, 2514-2519.

Le Boeuf, B. J.; Crocker, D. E.; Blackwell, S. B.; Morris, P. A. and Thorson, P. H. (1993), Sex differences in diving and foraging behaviour of northern elephant seals. Symposium of the Zoological Society, London, 66, 149-178.

Le Boeuf, B. J. (1994), Variation in the diving pattern of Northern elephant seals with age, mass, sex and reproductive condition. In: Le Boeuf, B. J.; Laws, R. 
M. (eds.). Elephant seals: Population ecology, behaviour, and Physiology. Berkley : University of California Press. pp. 253-270.

Lewis, M. N. (1996), El elefante marino del sur: biologia de la especie, descripción general de la agrupación de la Península Valdés y protocolos de trabajo. Informes técnicos del Plan de Manejo Integrado de la Zona Costera Patagónica (Puerto Madryn, Argentina), 16, 1-29.

McConnell, B. J. and Fedak, M. A. (1996), Movements of southern elephant seals. Canadian Journal of Zoology, 74 : (8), 1485-1496.

McConnell, B. J.; Chambers, C. and Fedak, M. A. (1992), Foraging ecology of southern elephant seals in relation to the bathymetry and productivity of the southern-ocean. Antarctic Sciences, 4 : (4), 393-398.

Martínes, P. E.; Colares, E. P.; Muelbert, M. M. C.; Robaldo, R. B. and Bianchini, A. (1998), Imobilização de elefantes marinhos do sul, Mirounga leonina, com tiletamina-zolazepan. 13. Annual Conference of the Federation of Experimental Biological Societies. Caxambú, MG, Brazil.

Muelbert, M. M. C. (1998), The influence of size at weaning on the transition to nutritional independence in the harbour seal: is bigger better? $\mathrm{Ph}$. D. Thesis. Dalhousie University, Halifax, N.S. Canada. 178 pp.

Rodhouse, P. G. (1988), Distribution of the neoteuthid squid Alluroteuthis antarticus Odhner in the Atlantic sector of the Southern Ocean. Malacologia, 29, 267-274.

Rodhouse, P. G.; Arnbom, T.; Fedak, M. A.; Yeatman, J. and Murray, A. W. A. (1992), Cephalopod prey of the southern elephant seal Mirounga leonina L. Canadian Journal of Zoology, 70, 1007-1015.

Stewart, B. S. (1997), Ontogeny of differential migration and sexual segregation in northern elephant seals. Journal of Mammalogy, 78 : (4), 1101-1116.

Van der Hoff, J. and Burton, H. R. (2001), Elephant seals as platforms for ocean monitoring. Southern hemisphere marine mammal conference. Phillip Is. Aus. pp. 144. [Abstract].

Received: August 20, 2002; Revised: July 28, 2003; Accepted: November 21, 2003. 